\title{
PENURUNAN KELUHAN DRIBBLING PASIEN PASCA TRANSURETHRAL RESECTION OF THE PROSTATE MELALUI KEGEL'S EXCERCISE
}

\author{
Abdul Madjid ${ }^{1,2^{*}}$, Dewi Irawaty ${ }^{3}$, Tuti Nuraini ${ }^{3}$ \\ 1. PSIK FK Universitas Hasanudin, Makassar 90245, Indonesia \\ 2. Program Studi Magister Fakultas Ilmu Keperawatan Universitas Indonesia, Depok 16424, Indonesia \\ 3. Fakultas Ilmu Keperawatan Universitas Indonesia, Depok 16424, Indonesia \\ *Email:pallet_oe@yahoo.co.id
}

\begin{abstract}
Abstrak
Penelitian ini bertujuan untuk mendapatkan gambaran pengaruh Kegel's exercise terhadap keluhan dribbling pasien pasca transurethral resection of the prostate (TURP). Sampel penelitian adalah responden yang dirawat di RS X dan RS Y yang memenuhi kriteria inklusi. Jumlah sampel pada kelompok intervensi sejumlah 10 responden, sedangkan kelompok kontrol 10 responden. Hasil penelitian menunjukan keluhan dribbling pada kelompok intervensi berhenti mulai hari ke-13, sedangkan pada kelompok kontrol berhenti mulai hari ke-24, sehingga membuktikan ada perbedaan yang signifikan rata-rata lama keluhan dribbling antara kelompok intervensi dan kelompok kontrol $(\mathrm{p}=0,007 ; \alpha=0,05)$. Penurunan lama keluhan dribbling pada responden yang patuh melakukan Kegel's exercise berhenti mulai hari ke-13, sedangkan pada responden yang tidak patuh berhenti mulai hari ke-20, sehingga membuktikan ada perbedaan yang bermakna rerata lama keluhan dribbling responden yang patuh melakukan Kegel's exercise dengan responden yang tidak patuh $(\mathrm{p}=0,004 ; \alpha=0,05)$. Simpulan dari penelitian ini adalah Kegel's exercise terbukti dapat menurunkan keluhan dribbling pasien pasca TURP. Disarankan agar tiap rumah sakit dapat menerapkan Kegel's excercise terhadap pasien dengan keluhan dribbling pasca-TURP.
\end{abstract}

Kata Kunci: Kegel's exercise, keluhan dribbling, pasca transuretral resection of the prostate (TURP), patuh Kegel's exercise

\begin{abstract}
This study aims to see the effect of Kegel's exercise on Dribbling Complaint of Post Transurethral Resection of the Prostate (TURP) patient. The sample was the patients who are hospitalized in X hospital and Y hospital fulfill the inclusion criteria. There were 10 responden each for intervention and control groups. The study results show that dribbling complaint of patient in intervention group stop at day 13, while in control group stop at day 24. Thus, there is a significant difference of the average of dribbling complaint duration between intervention and control groups $(p=0.007 ; \alpha=0.05)$. In addition, for the respondents in intervention group who did the exercise regularly, the dribbling complaint stop at day 13 and those who did not do exercise regularly the complaint stop at day 20. This is shown again that there is a significant difference of the average of dribbling complaint duration between those who do the exercise regularly and who do not do it regularly $(p=0.004 ; \alpha=0.05)$. In conclusion, the Kegel's's exercise is proven can reduce the dribbling complaint of post TURP patient. It is recommended that each hospital can apply Kegel's excercise for patients with symptoms of post-TURP dribbling.
\end{abstract}

Key words: Kegel's's exercise, dribbling complaint, post transuretral resection of the prostate (TURP), do Kegel's exercise regularly

\section{Pendahuluan}

Kelainan kelenjar prostate merupakan penyakit yang sering ditemukan khususnya di negara-negara berkembang seperti Indonesia. Kelainan kelenjar prostate dikenal Benigna Prostat Hiperplasia (BPH) yaitu berupa pembesaran prostat atau hiperplasia prostat (Rahardjo, 1999). Di Indonesia, BPH merupakan urutan kedua setelah batu saluran kemih dan diperkirakan ditemukan pada $50 \%$ pria berusia diatas 50 tahun dengan angka harapan hidup rata- rata di Indonesia yang sudah mencapai 65 tahun (Furqan, 2003).

Sjamsuhidajat dan Jong (2005) menjelaskan BPH merupakan hiperplasia kelenjar periuretral yang mendesak jaringan prostat yang asli ke perifer. Pembesaran prostat menyebabkan penyempitan lumen uretra prostatika sehingga menghambat aliran urin. Keadaan ini menyebabkan peningkatan intravesikal ke seluruh bagian kandung kemih sampai pada kedua muara ureter, sehingga akibat 
tekanan tinggi menimbulkan aliran balik urin dari kandung kemih ke ureter dan menimbulkan refluk vesiko-ureter. Refluks vesiko ureter menyebabkan hidroureter, hidronefrosis dan pada akhirnya akan menyebabkan gagal ginjal (Purnomo, 2005).

Transuretral Resection of The Prostate (TURP) merupakan salah satu tindakan pembedahan untuk mengatasi obstruksi pada saluran kemih. TURP merupakan tindakan pembedahan via endoscopy transuretral tanpa melakukan pembedahan/insisi terbuka. Angka mortalitas pasien TURP sebesar 1 $-2 \%$, sedangkan angka keberhasilan TURP dalam mengatasi gejala klinik akibat BPH sebesar $88 \%$ (Leslie, 2006).

RS X dan RS Y menjadi salah satu alternatif pelayanan pasien BPH dengan operasi TURP di kawasan Indonesia timur, khususnya Makassar. Usia pasien BPH yang dirawat di RS X $85 \%$ berusia $\geq 50$ tahun. Sedangkan usia pasien yang dirawat di RS Y $95 \%$ berusia > 50 tahun. Laberge (2009) memaparkan salah satu komplikasi pasca TURP adalah inkontinen urin. Ketidakmampuan seseorang dalam mengontrol urin setelah menjalani pasca TURP, ditandai dengan urin yang menetes setelah buang air kecil yang disebut dribbling. Jika hal ini tidak segera di tanggulangi, $2-4 \%$ dari beberapa pasien dapat menderita inkontinen total.

Dribbling yang terjadi karena pembesaran kelenjar prostat/BPH menyebabkan obstruksi pada urethra sehingga urin akan tertahan di sekitar uretra akibat instabilitas relaksasi sfingter uretra oleh karena pembesaran lumen di sekitar prostat, leher bulibuli hingga ke urethra ekternal maupun internal. Hal ini di tandai oleh divertikuli membran sekitar. Dribbling akibat pasca TURP disebabkan oleh lumen sekitar leher buli-buli lesi sehingga impuls saraf yang diteruskan menuju urethra terganggu. Hal ini mengakibatkan fase pengosongan urin terganggu akibat maksimalisasi relaksasi sfingter urethra kurang. Kelemahan otot dasar pelvis akibat $\mathrm{BPH}$ ataupun pasca operasi prostat dapat menjadi penyebab timbulnya dribbling (Sjamsuhidajat \& Jong, 2005).
Paterson, Pinnock, dan Marshall (1997), yang menjelaskan keluhan dribbling setelah berkemih merupakan hal yang sangat memalukan pada sebagian pria, khususnya pada pasien yang telah menjalani operasi TURP. Kegel's exercise/latihan otot dasar pelvis pasca TURP dapat memperbaiki keluhan tersebut. Paterson, Pinnock, dan Marshall (1997) dan Chang, et al. (1998) menerangkan bahwa pemberian latihan otot dasar pelvis dapat memperbaiki urodinamik pada kasus inkontinen urin khususnya dalam mengatasi keluhan dribbling. Latihan otot dasar pelvis atau Kegel's exercise dapat meningkatkan resistensi uretra, disertai dengan penggunan otot dasar pelvis secara sadar oleh pasien sehingga dapat mencegah keluhan dribbling pasca TURP. Fungsi penyokong dari otot dasar pelvis dapat membantu menyokong organ sekitar pelvis sehingga peran dari sfingter uretra dalam urodinamik pasca TURP menjadi meningkat seiring perbaikan sensitifitas sfingter uretra fase pengosongan kandung kemih.

Porru, et al. (2001) menjelaskan dampak latihan dini kegel's exercise setelah pasien menjalani operasi TURP menunjukkan hasil perbaikan kemampuan berkemih. Kemampuan ini ditandai dengan penurunan keluhan dribbling setelah berkemih dan penurunan episode inkontinen urin pasca TURP. Tibaek, et al. (2007) mengevaluasi efek pengaruh latihan otot dasar pelvis sebelum pasien menjalani TURP. Pre operative latihan otot dasar pelvis menunjukkan peningkatan yang signifikat terhadap daya tahan otot dasar pelvis pasca TURP, meskipun secara klinik keterkaitan peningkatan status urodinamik pasca TURP tidak ada perbedaan.

Fenomena dan gambaran tersebut menjelaskan bahwa dalam memberikan asuhan keperawatan merupakan hal yang penting bagi perawat untuk merencanakan intervensi yang tepat pre dan pasca operasi khususnya pemberian latihan kegel's exercise dalam mengatasi dribbling pasien pasca TURP. Pemberian latihan tersebut tidak hanya bermanfaat memperbaiki urodinamik, namun dapat mengurangi resiko retensi urine pasien pasca TURP 
serta dapat meningkatkan kualitas hidup pasien. Sehingga dapat menunjukan pula bentuk tindakan mandiri perawat sebagai perawat medikal bedah. Berdasarkan permasalahan tersebut, maka peneliti merasa perlu untuk mengetahui dan mempelajari pengaruh kegel's exercise terhadap keluhan dribbling pasien pasca TURP.

\section{Metode}

Penelitian menggunakan metode penelitian quasi eksperimental dengan pre-test and pasca-test with control group. Populasi adalah seluruh pasien pasca TURP dengan keluhan dribbling yang berada di RS X dan RS Y. Penentuan jumlah sampel (sampling) dalam penelitian menggunakan metode restriksi yaitu penerapan kriteria pembatasan dalam memilih subjek penelitian. Adapun kriteria sampel antara lain; (1) kriteria inklusi; tidak mengalami gangguan kognitif, tidak mengalami gangguan persarafan spinal cord injury, tidak mengalami striktur uretra, sudah menjalani operasi TURP, tidak mengalami gangguan fungsi ginjal, level PSA menunjukkan $>10 \mathrm{ng} / \mathrm{ml}$, mengalami keluhan dribbling pasca TURP, mampu melakukan kegel's exercise, tidak mendapatkan obat-obatan yang membuat dialatasi otot, disetujui oleh dokter untuk dilakukan kegel exercise, dan bersedia menjadi responden. Sedang (2) kriteria eksklusi; mengalami penyakit terminal, mengalami pelvic floor prolaps stadium $I V$, mengalami gejala infeksi pada saluran kemih, konstipasi, dan mengalami konstipasi, batuk kronik atau bronkhitis kronik serta asma.

Pengambilan sampel menggunakan probabiliy sampling dengan simple random sampling. Penelitian ini dilaksanakan di RS X dan RS Y pada Mei - Juni 2009. Total jumlah responden dalam penelitian ini 10 responden kelompok intervensi dan 10 responden kelompok kontrol. Pengumpulan data dilakukan dengan menggunakan lembar kuesioner dan lembar observasi. Lembar kuesioner terkait karakteristik responden, keluhan dribbling dan kepatuhan melakukaan kegel's exercise. Lembar observasi terkait informasi keluhan dan kepatuhan responden melakukan kegel's exercise selama empat minggu/ 28 hari. Pengisian lembar kuesioner dilakukan oleh responden berdasarkan informasi keluhan dribbling dan intensitas kegel's exercise selama 4 minggu. Peneliti melakukan kunjungan atau pertemuan di setiap minggunya. Kuesioner yang digunakan, menurut Burns dan Grove (2001), bahwa validitas konstruk menguji kesesuaian antara definisi konseptual dan definisi operasional.

Hasil uji realibilitas terhadap modifikasi kuesioner keluhan dribbling dan tingkat kepatuhan pada nilai r tabel $(0,423)$ menunjukkan nilai $r$ alpha $(0,488)$, artinya realibilitas kuesioner keluhan dribbling dan tingkat kepatuhan dinyatakan reliabel. Hasil corrected item-total uji validitas diperoleh $\mathrm{r}=0,469$ dimana $r$ yang diperoleh lebih besar dari $r$ tabel sehingga disimpulkan pertanyaan valid. Lembar voiding dairy dalam penyesuaian tidak dilakukan suatu uji. Asumsi peneliti didasarkan pengunaan voiding dairy sejenis digunakan berdasarkan tujuan dan fungsi pengamatan yang akan diobservasi.

\section{Hasil}

Hasil penelitian didasarkan pada analisa univariat, bivariat dan multivariat. Analisis hasil penelitian univariat, yaitu: data demografi; umur responden, pre-test dan pasca-test keluhan dribbling, lama keluhan dribbling berlangsung serta tingkat kepatuhan responden dalam melakukan kegel's exercise baik kelompok intervensi maupun kontrol. Hasil analisis data numerik disajikan dalam bentuk mean, median, modus, standart deviasi, dan 95\% CI serta pada data kategorik disajikan dalam bentuk distribusi frekuensi.

Analisis bivariat untuk membuktikan hipotesis penelitian terhadap perubahan keluhan dribbling pre-test dan pasca-test kegel's exercise pada kelompok intervensi dengan kelompok kontrol terkait ada atau tidak ada perbedaan rerata umur responden dan lama keluhan dribbling antara kelompok intervensi dan kelompok kontrol, serta memperlihatkan pula ada atau tidak ada perbedaan lama keluhan dribbling antara tingkat kepatuhan 
kelompok intervensi. Analisis ini menggunakan uji statistik independent t-test dengan tingkat kepercayaan $95 \%$.

Hasil analisis menurut tingkat kepatuhan, pada kelompok intervensi ada 4 orang $(40 \%)$ responden patuh melakukan kegel's exercise dan ada 6 orang $(60 \%)$ responden tidak patuh melakukan kegel's exercise. Sedangkan pada kelompok kontrol ada 10 orang $(100 \%)$ responden yang tidak melakukan. Hasil penelitian menjelaskan $40 \%$ responden yang patuh melakukan latihan menunjukkan perubahan keluhan dribbling pada minggu ke-2 dan minggu ke-3, bahkan 1 responden diantaranya dalam 13 hari sudah tidak menunjukkan keluhan dribbling.

Hasil uji analisis rerata lama keluhan dribbling responden yang patuh melakukan kegel's exercise adalah 17,25 hari ( $\mathrm{SD}=2,986$ hari), sedangkan untuk rerata lama keluhan dribbling responden tidak patuh melakukan kegel's exercise adalah 24.17 hari $(\mathrm{SD}=2,483$ hari). Terlihat perbedaan nilai mean antara responden yang patuh melakukan kegel's exercise dan responden yang tidak patuh melakukan yaitu 6,92 hari ( $\mathrm{SD}=0,503$ hari). Ada perbedaan yang bermakna antara lama keluhan dribbling responden yang patuh melakukan kegel's exercise dan responden yang tidak patuh melakukan kegel's exercise $(\mathrm{p}=0,004 ; \alpha=0,05)$.

\section{Pembahasan}

Usia termuda 54 tahun dan usia tua 75 tahun dengan rata-rata usia responden 64,50 tahun diperoleh pada kelompok intervensi. Sedangkan pada kelompok kontrol diperoleh usia termuda 48 tahun dan usia tua 79 tahun dengan rata-rata usia responden 65,00 tahun. Keterangan tersebut menjelaskan bahwah $100 \%$ usia pada kelompok intervensi $>50$ tahun, sedangkan pada kelompok kontrol 20\% $\leq 50$ tahun, yaitu 1 responden (10\%) yang berusia 48 tahun dan 1 responden (10\%) berusia 50 tahun.

Purnomo (2005) menjelaskan bahwa hiperplasia prostat muncul pada lebih dari $50 \%$ laki-laki berusia 50 tahun keatas. Pasien yang berusia 50 tahun, diantaranya $30 \%$ pria berusia $70-80$ tahun dan $75 \%$ pada usia lanjut berusia lebih dari 80 tahun. Sedangkan, Rahardjo (1999) menjelaskan pula beberapa pria usia lanjut dapat mengalami pembesaran prostat. Keadaan ini dialami 50\% lakilaki berusia 60 tahun dan kurang lebih $80 \%$ lakilaki berusia 80 tahun.

Literatur menjelaskan hiperplasia prostat/BPH ialah pertumbuhan nodul-nodul fibroadenomatosa majemuk dalam prostat akibat dari perubahan keseimbangan testosterone-esterogen. Darmojo (2009) menyatakan usia 25 - 30 tahun timbul nodul mikroskopik kelenjar prostat sudah dapat terlihat.

Sjamsuhidajat dan Jong (2005) menjelaskan pula berdasarkan angka autopsi perubahan mikroskopik prostat sudah dapat ditemukan pada usia $30-40$ tahun sehingga seiring bertambah usia, perubahan mikroskopik prostat akan berkembang kearah patologik. Sehingga hasil penelitian yang dilakukan peneliti menemukan sebesar $10 \%$ dari total jumlah responden pada kelompok kontrol memiliki usia $\leq 50$ tahun yaitu 48 tahun. Berdasar studi literatur tersebut menjelaskan responden pada usia 48 tahun memungkinkan dapat menunjukkan perubahan makroskopik prostat yang berkembang kearah patologik sehingga responden tersebut menjalani reseksi prostat/TURP.

Pada kelompok intervensi ada seorang responden (10\%) tidak mengalami keluhan dribbling pada minggu ke-2 dan empat responden (40\%) tidak mengalami keluhan dribbling di minggu ke-3. Sedangkan, kelompok kontrol tidak ada responden yang tidak mengalami keluhan dribbling di minggu ke-2 dan 7 responden (70\%) tidak mengalami keluhan dribbling di minggu ke-3. Darmojo (2009) menjelaskan bahwa dribbling merupakan obstrukti urethra akibat pembesaran prostat, striktur urethra, dan kanker prostat yang dapat menyebabkan inkontinensia pada pria lanjut usia. Hal ini ditandai dengan adanya urin yang menetes setelah berkemih.

Dribbling yang terjadi karena pembesaran kelenjar prostat/BPH menyebabkan obstruksi pada urethra 
sehingga urin akan tertahan di sekitar urethra akibat instabilitas relaksasi sfingter urethra oleh karena pembesaran lumen di sekitar prostat, leher bulibuli hingga ke urethra ekternal maupun internal, ditandai ada divertikuli membran sekitar. Dribbling akibat pasca TURP disebabkan lumen sekitar leher buli-buli lesi sehingga impuls saraf yang akan diteruskan menuju urethra terganggu. Hal ini mengakibatkan fase pengosongan urin terganggu akibat relaksasi sfingter urethra kurang maksimal. Kelemahan otot dasar pelvis akibat BPH ataupun pasca operasi prostat dapat menjadi salah satu penyebab timbulnya dribbling (Sjamsuhidajat \& Jong, 2005).

Latihan otot dasar pelvis atau Kegel's exercise yang dilakukan dengan benar dapat menguatkan otot dengan meningkatkan resistensi uretra melalui penyokongan pada otot dasar pelvis yang dilakukan secara berulang-ulang. Penggunaan otot secara sadar oleh pasien untuk mencegah dribbling pasca TURP dapat membantu terbentuk reseptor saraf pasca reseksi prostat sehingga sensitifitas urethra terhadap sensorik somatik kembali peka. Selain itu, sifat sel saraf yang reversibel dapat membantu pemulihan urodinamik pasca TURP, khususnya terhadap keluhan dribbling. Hal ini dibuktikan dengan perkembangan penurunan keluhan setiap minggu (Baum, 2003).

Paterson, Pinnock, dan Marshall (1997); Chang, et al. (1998) menambahkan pemberian latihan otot dasar pelvis dapat memperbaiki urodinamik pada kasus inkontinen urin khususnya dalam mengatasi dribbling. Selain itu, Porru, et al. (2001) terhadap penelitian di Italia mengenai dampak latihan dini kegel's exercise setelah pasien menjalani operasi TURP. Hasil yang diperoleh penurunan keluhan dribbling setelah menjalani kegel's exercise pada minggu pertama menunjukkan penurunan keluhan dribbling. Berdasarkan hal tersebut bahwa dampak latihan otot dasar pelvis/ kegel's exercise dapat memperbaiki fungsi urodinamik pasca TURP khususnya pada keluhan dribbling.

Analisis sebelumnya menjelaskan menurut tingkat kepatuhan, pada kelompok intervensi ada empat responden $(40 \%)$ patuh melakukan latihan kegel's exercise dan 6 responden $(60 \%)$ yang tidak patuh melakukan latihan kegel's exercise. Sedangkan pada kelompok kontrol 10 responden (100\%) tidak melakukan kegel's exercise dan tidak ada responden yang patuh melakukan kegel's exercise. Riwayat penelitinan menjelaskan bahwa $40 \%$ responden patuh melakukan latihan menunjukkan perubahan keluhan dribbling pada minggu ke-2 dan minggu ke-3. Satu responden diantaranya dalam 13 hari sudah tidak menunjukkan keluhan dribbling. Berdasarkan hasil dapat disimpulkan tingkat kepatuhan melakukan kegel's exercise dapat membantu menurunkan keluhan dribbling lebih cepat. Lama keluhan dribbling pada kelompok kontrol satu responden (10\%) dalam 24 hari sudah tidak menunjukkan keluhan dribbling.

Baum (2003) menjelaskan bahwa latihan otot dasar pelvis atau Kegel's exercise yang dilakukan dengan benar dapat menguatkan otot dengan meningkatkan resistensi uretra melalui penyokongan otot dasar pelvis yang dilakukan berulang-ulang. Penggunan otot secara sadar oleh pasien untuk mencegah dribbling pasca TURP dapat membantu terbentuk reseptor saraf pasca reseksi prostat sehingga sensitifitas urethra terhadap sensorik somatik kembali peka.

\section{Kesimpulan}

Keluhan dribbling pada kelompok intervensi berhenti mulai hari ke-13, sedang pada kelompok kontrol berhenti mulai hari ke-24 ( $\mathrm{p}=0,007 ; \alpha=$ 0,05). Penurunan lama keluhan dribbling pada responden yang patuh melakukan kegel's exercise berhenti mulai hari ke-13, sedang pada responden tidak patuh melakukan latihan kegel's exercise berhenti mulai hari ke-20 ( $\mathrm{p}=0,004 ; \alpha=0,05)$. Hasil analisa lebih lanjut menjelaskan ada perbedaan yang bermakna pada rerata lama keluhan dribbling responden diantara tingkat kepatuhan melakukan kegel's exercise pada kelompok intervensi dan kelompok kontrol $(p=0,0005 ; \alpha=0,05)$.

Penentu kebijakan di rumah sakit maupun layanan kesehatan di masyarakat hendaknya agar dapat 
mengembangkan protap intervensi keperawatan dalam pelaksanaan manajemen konservatif pasien dengan keluhan dribbling khususnya pasien pasca operasi prostat. Perawat dalam merawat pasien dengan keluhan dribbling dapat mengutamakan pemilihan kegel's exercise sebagai bentuk dari intervensi keperawatan yang berkaitan dengan latihan fisik, sehingga dapat memberi efek positif bagi pasien dengan keluhan dribbling khususnya pada manajemen pasien pasca operasi prostat. Kegel's exercise pada pasien dengan keluhan dribbling dalam penelitian ini menunjukkan ada penurunan keluhan dribbling. Hal ini dapat dijadikan untuk dibuatkan suatu program atau standar operasional prosedur terhadap pasien dengan keluhan dribbling pasca TURP sehingga dapat dijadikan tindakan antisipatif bagi pasien sebelum menjalani operasi TURP.

Perlu dilakukan penelitian lebih jauh terhadap pasien pasca operasi prostat lain dengan keluhan sejenis melalui latihan dini sebelum dan sesudah menjalani operasi prostat sesuai indikasi, serta penelusuran variabel lain yang sempat tidak diteliti peneliti seperti fungsi urodinamik, adanya riwayat infeksi dan jenis reseksi dapat menjadi acuan peneliti berikutnya terhadap efektivitas pemberian latihan kegel's exercise dini sebelum dan sesudah operasi prostat (TG, ENT, TN).

\section{Referensi}

Baum, N. (2003). Pelvic floor exercise for men. Diperoleh dari http://www.neilbaum.com/articles/ ui_pelvic_exercises.shtml.

Burns, N., \& Grove, S.K. (2001). The practice of nursing research: Conduct, critique, \& utilization (4th Ed.). Philadelphia: W.B. Sauders Company.

Chang, L.P., Tsai, H.L., Huang, T.S., Wang, M.T., Hsieh, L.M., \& Tsui, H.K. (1998). The early effect of pelvic floor muscle exercise after transurethral prostatectomy. J Urology, 160 (2), 402-405.

Darmojo, B. (2009). Buku ajar Boedhi-Darmojo "Geriatri, ilmu kesehatan usia lanjut". Jakarta: Balai Penerbit Fakultas Kedokteran Universitas Indonesia. (Hal 226-242; 495-505).
Furqan. (2003). Evaluasi biakan urin pada penderita BPH setelah pemasangan kateter menetap: Pertama kali dan berulang. Medan: Bagian Ilmu Bedah Fakultas Kedokteran Universitas Sumatera Utara. Diperoleh dari http://library.usu.ac.id/ download/fk/bedah-furqan.pdf.

Laberge, M. (2009). Transurethral resection of the prostate. Diperoleh dari http://www.answers.com/ topic/transurethral-resection-of-the-prostate.

Leslie, W.S. (2006). Transurethral resection of the prostate. Diperoleh dari http://emedicine. medscape.com/article/449781-overview.

Murti, B. (1997). Prinsip dan metode riset epidemologi. Yogyakarta: Gadjah Mada University Press.

Paterson, J., Pinnock, C.B., \& Marshall., V.R. (1997). Pelvic floor exercises as a treatment for postmicturition dribble. Br J Urol., 79 (6), 892-897 (ISSN: 0007-1331).

Porru, D., Campus, G., Caria, A., Madeddu, G., Cucchi, A., Rovereto, B., Scarpa, M.R., Pili, P., \& Usai, E. (2001). Impact of early pelvic floor rehabilitation after transurethral resection of the prostate. Neurology and urodinamics, 20 (1), 53-59.

Purnomo, B.B. (2005). Dasar-dasar urologi (Edisi ke-2). Jakarta: Penerbit Sagung Seto. (Hal 79-81).

Rahardjo, D. (1999). Prostat "Kelainan - kelainan jinak, diagnosa dan penanganan”. Jakarta: Subbagian Urologi Bagian Bedah Fakultas Kedokteran Universitas Indonesia, Asian Medical.

Sjamsuhidajat, R., \& Jong, de.W. (2005). Buku ajar ilmu bedah (Edisi 2). Jakarta: Penerbit Buku Kedokteran EGC. (Hal 782-786).

Srigondo, B. (1981). Jumlah ulangan dalam percobaan, dalam rancangan percobaan. Semarang: Universitas Diponegoro Press. (Hal 101-106).

Tibaek, S., Klarskov, P., Lund, H.B., Thomsen, H., Andresen, H., Schmidt, J.C., \& Niemann, O.M. (2007). Pelvic floor muscle training before transurethral resection of the prostate: A randomized, controlled, blinded study. Scandinavia Journal of Urology and Nephrology, 41 (4), 329-334. 